\title{
ON EFFICIENT OPERATIONAL CONCEPT OF FUTURE HIGH-SPEED RAILWAY IN THE CZECH REPUBLIC
}

\author{
Michal DRÁBEK
}

\begin{abstract}
Department of Logistics and Management of Transport, Faculty of Transportation Sciences, CTU in Prague, Czech Republic

correspondence: xdrabek@fd. cvut.cz
\end{abstract}

\begin{abstract}
The aim of this paper is to elaborate a layout of the first operational concept of Rapid Services with 1 hour system travel time between Praha and Brno. Two basic methods are used Integrated Periodic Timetable (periodic rendezvous of all services in IPT-nodes) and Operational Concept Economy Approach, as defined below by the author. In this paper, three recent high-speed railway concepts for the future so-called Rapid Services network of the Czech Republic are followed-up. The first one is an operational traffic planning study by Kalčík, Janoš et al. on behalf of Czech Ministry of Transport from 2010. The second one is the high-speed railway promoting book High Speed Rail Even in the Czech Republic by Šlegr et al. from 2012, with likely the most detailed concept of Rapid Services network. The third one is a paper on progress of the official spatial-technical studies for some future Czech high-speed lines by Šulc from 2014. The importance of achievement of 1 hour travel time between the largest agglomerations is briefly presented. The presented methodological approach, although soft and manager-oriented, comprises some firm principles: segmentation of high-speed train offer, so that more expensive rolling stock is not wasted by operation on long conventional line sections, consideration of system travel times for efficient rolling stock circuit, restriction of need for links from high-speed to conventional lines, and utilization of high-speed lines as a "rail highway". This approach is intended to be particularized iteratively, with every application. So, in this paper, first version of Operational Concept Economy Approach is introduced. The key idea is that passengers should be offered such travel times and service intervals (headways) and such number of direct services, which are adequate to their potential demand, but as much synergistic effect as possible should be strived to be achieved for every proposed construction (new or modernized one). Such approach goes towards economic efficiency, which is crucial indicator for political decision necessary for building, let alone EU co-funding of the construction. Experience shows that in many Czech feasibility studies, achievement of sufficient economic efficiency was the most complicated part of the study. Results show that an efficient operational concept can be designed not at the expense of runtimes between the largest cities.
\end{abstract}

Keywords: high-speed railway, high-speed line, Rapid Services, Integrated Periodic Timetable .

\section{INTRODUCTION}

The aim of this paper is to elaborate a layout of the first operational concept of Rapid Services with 1 hour system travel time between Praha and Brno. Two basic principles are used - Integrated Periodic Timetable, and Operational Concept Economy Approach, as defined below by the author. Directive 2008/57/EC of the European Parliament and of the Council of 17 June 2008 on the interoperability of the rail system within the Community [1] defines in Annex II infrastructure and rolling stock as structural subsystems of the rail system, and traffic operation and management as a functional subsystem of the rail system. In traffic operation and management subsystem, traffic planning is also included. This paper is organized as follows. After list of abbreviations and list of largest Czech cities, recent concepts of high-speed lines network for Rapid Services, in the context of recent TEN-T regulation [2] are introduced. Then, significance of 1 hour travel time is summarized, based mostly on revealedpreference data. Introduction of used methods follows:
Integrated Periodic Timetable and newly developed soft Operational Concept Economy Approach. Further, scheme of the resulting operational concept is presented, commented and discussed. The paper is closed by conclusion, including recommendation for further studies in this field.

For the sake of brevity and clarity, following abbreviations will be used in this paper:

- EMU - electric multiple unit

- HS - high-speed (railway)

- HSL - high-speed line

- IPT - Integrated Periodic Timetable

- PuT Line - public transport line (not to be mistaken with railway line as a built structure) - a group of services which operate all day in regular period, and serve particular sequence of stations and stops

- RS - Rapid Services (Czech system of HSLs and follow-up uprgraded or new lines, in Czech: Rychlá spojení) 
- SŽDC - Railway Infrastructure Administration, state organization - Czech State Railway Infrastructure Manager ( in Czech: Správa železniční dopravní cesty )

- TEN-T - Trans-European Transport Networks

- TSI - technical specification of interoperability

- UIC - International Union of Railways

\section{List of largest Czech Cities}

Table 1 displays list of all Czech cities over 40,000 inhabitants. These cities can be divided into four subgroups based on their population, as of 1st January 2015. Regional capitals are emphasized. Note that population of Ostrava agglomeration is comparable with Praha. These cities build up five largest agglomerations: Praha, Ostrava region, Brno, Northwestern Bohemia (from Děčín to Chomutov) and Central Moravia.

\section{TEn-T Context and Recent CONCEPTS OF HSLS FOR RAPID SERVICES}

Most of the intended Czech HSLs are part of TEN-T network, but only three of them are involved into the core TEN-T network: HSLs Praha - Ústí nad Labem and Brno - Břeclav, and modernization of the line Brno - Přerov. For the HSL Brno - Břeclav, there are several alternative directions southward of Vranovice. For the HSL Praha - Wroclaw (in comprehensive network), there are two alternative directions: via Liberec or via Hradec Králové. The author has followed up from three main sources. Each one has been carried out for different purpose. The study carried out by Kalčík, Janoš et al. (including the author) [4] contains, to the author's knowledge, the only model timetable for the whole RS network up to now. Approximate routes for HSLs were defined, and, based on their parameters and on available HS rolling stock parameters, model timetables were constructed using timetabling software FBS. One of the results is a netgraph (scheme of $\mathrm{PuT}$ lines with arrival and departure minutes in node stations). Šlegr et al. [5] have written and published the book High Speed Rail Even in the Czech Republic with many HSL drawings in the map. The book introduces European and world best practice in HS railway and, in a detailed manner, presents potential benefits of the RS system for every Czech region. As a result, the most detailed concept of RS network (although not officially approved), with qualified estimation of section runtimes, is introduced there. Sulc 6 has presented recent progress in five spatial-technical studies of HSLs, carried out on behalf on SŽDC. The aim of these studies is to find suitable HSL routes, so that necessary space for their future construction can be legally protected. For this purpose, simplified timetable layout and cost estimation were carried out. Other HSLs were already subject of more detailed feasibility studies: Praha - Liberec and Brno - Přerov. The latter study recommended the doubling and modernization of present single-track line up to $200 \mathrm{~km} / \mathrm{h}$ as the best one, although the assessed line is located directly in the corridor Brno - Ostrava. UIC [7] records that HSLs for the maximum speed of $350 \mathrm{~km} / \mathrm{h}$ are in operation in China $(1,028 \mathrm{~km})$, and they are planned in Portugal $(206 \mathrm{~km})$. In the United Kingdom, HSLs for the maximum speed of $360 \mathrm{~km} / \mathrm{h}(543 \mathrm{~km})$ are planned. Thus, such maximum speed is nothing uncommon for the recently built and planned HSLs. Figure 1 shows the maximalist future Czech HSL network as a backbone of Rapid Services. It does not include possible local new lines or line modernizations. The scheme was created as follows. For each HSL, always the higher maximum speed from Šlegr et al. [5] and Šulc 6] was chosen. Inclusion of each HSL (or its section) into TEN-T core, or comprehensive network based on [2] was marked. The actual phase of project preparation (based on Šulc [6] and to the author's knowledge) was also marked. From the possible links to conventional railway network, only the most significant ones were displayed. The stations or stops, which are intended to be built directly on HSLs were adopted from Šulc [6]. International HSLs are strongly dependent on the will of both neighbouring states: the HSL from Ústí nad Labem to Dresden is supported by Czech Ministry of Transport, as well as the government of Saxony (although it requires a long tunnel under the mountains), but the HSL from Plzeñ to Bavaria is not quite a priority for the government of Bavaria, despite its indisputable European significance.

\section{One Hour as a Breakthrough in TRAvel Time}

The practice has proven that, when the public transport travel time changes to 1 hour or less, and if this travel time is competitive to car, public transport ridership considerably increases, and some people can even commute daily. If the present travel time by cars between two largest Czech cities is approximately 2 hours, only 1 hour is fully competitive, because the travel time to and from the station must be added. In Switzerland, new line for $200 \mathrm{~km} / \mathrm{h}$ was built to achieve travel time of $56 \mathrm{~min}$ between Zurich and Berne (Swiss largest city and capital). This line was not an isolated project, but a part of targeted investments for implementing Bahn 2000 concept. Its main aim was to achieve necessary system travel times for the IPT. This new line, as a kind of Swiss "rail highway", serves also for many other long-distance PuT lines. The Modal-Split of railway for the journeys Zurich - Berne has achieved $88 \%$, for the journeys Zurich - St. Gallen (1:02 $\mathrm{h}$ travel time) it was $73 \%$ (VOeV UTP, 2010 [8]). Janoš and Baudyš [9] state that improvements in 


\begin{tabular}{||c|c||c|c||}
\hline \hline City & Population & City & Population \\
\hline \hline Praha & $1,259,079$ & Zlín & 75,112 \\
\hline Brno & 377,440 & Havírov & 75,049 \\
\hline Ostrava & 294,200 & Kladno & 68,552 \\
\hline & & Most & 67,089 \\
\hline & & Opava & 57,772 \\
\hline & & Frýdek Místek & 56,945 \\
\hline & & Karviná & 55,985 \\
\hline \hline City & Population & City & Population \\
\hline \hline Plzeň & 169,033 & Jihlava & 50,521 \\
\hline Liberec & 102,562 & Teplice & 50,079 \\
\hline Olomouc & 99,809 & Děčín & 49,833 \\
\hline Ústí nad Labem & 93,409 & Karlovy Vary & 49,781 \\
\hline Ceské Budějovice & 93,285 & Chomutov & 48,913 \\
\hline Hradec Králové & 92,808 & Jablonec nad Nisou & 45,594 \\
\hline Pardubice & 89,693 & Mladá Boleslav & 44,318 \\
\hline & & Přerov & 44,278 \\
\hline & & Prostějov & 44,094 \\
\hline \hline
\end{tabular}

TABle 1. List of largest Czech cities. Data from Czech Statistical Office [3].

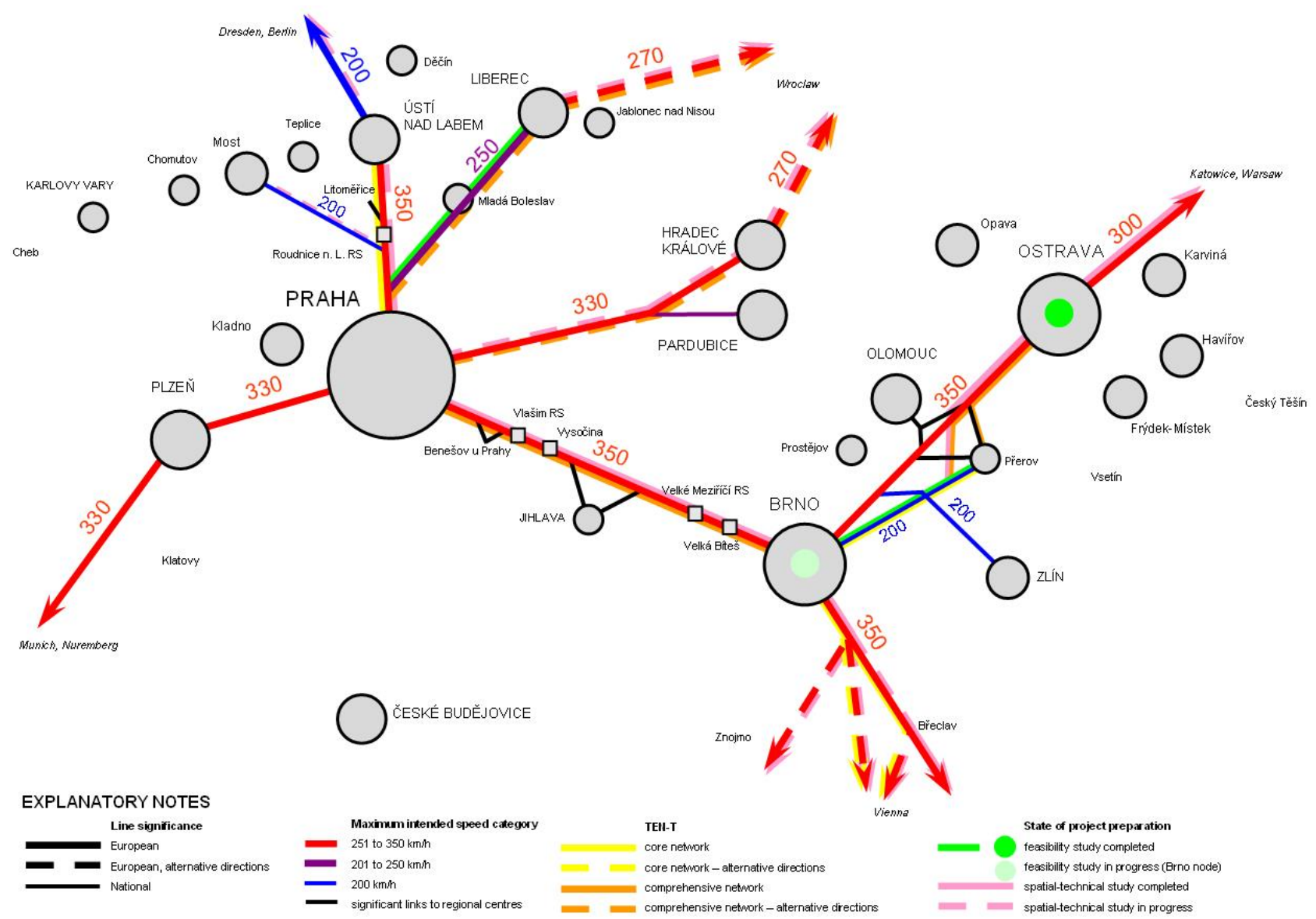

Figure 1. Maximalist Czech HSL network 
timetable offer (more frequent and more periodic service) in long-distance railway in the Czech Republic have led to increase of number of passengers. "Between 2003 and 2005, incomes increased by $7.86 \%$, and number of passengers by $3.63 \%$. However, in some relations, thanks to new supply, the increase of passengers was 40 to $50 \%$. IPT is being further developed. Thanks optimal train connections in junctions and synergic effect of linked supply number of passengers raises by $2-10 \%$ per year even on lines with no supply change." The raise of service for timetable 2004/05 was 7\%, compared to timetable 2003/04, when new offer (supply) concept was introduced. Vichta [10 has also shown figures that justified timetable offer improvement for large enough cities (Ústí nad Labem and Teplice). Since 2003/04 timetable, two segments of periodic service between Ústí and Praha were introduced: a non-stop fast train with travel time slightly above 1 hour and a $120 \mathrm{~min}$ interval, and fast train with several stops hourly. Since 2008, a non-stop segment has been operated hourly, and every second service connected Teplice directly with Praha. Compared with train ridership from 2002 $(100 \%)$, the train ridership between Ústí and Praha grew to $152 \%$ in 2006 , and to $325 \%$ in 2008 . Compared to the same year, the train ridership between Teplice and Praha grew to $228 \%$ in 2006 and to $369 \%$ in 2008 . In both cases, only relative changes can be published, to avoid publishing of Czech Railways' business sensitive data. KORDIS JMK, an integrated transport system coordinator of South Moravia Region, has carried out a stated-preference study of potential ridership of HSL between Praha and Brno [11]. The study has proved that about 30,000 passengers daily would use the new HSL, majority of them instead of cars. The potential ridership varied depending on train travel time and ticket price. The results for $45 \mathrm{~min}$ travel time were only slightly better than the ones for $60 \mathrm{~min}$. The acceptable ticket price was up to 299 CZK. For 300 CZK and more, the potential ridership fell to approximately 18,000 passengers. A travel time between Praha and Brno up to $60 \mathrm{~min}$ is also supported officially, at least by some departments of Czech Ministry of Transport and SŽDC - see Šulc, page 14 [6] and Kušnír and Ilík, page 13 [12]. The graph in the latter presentation shows clear intention to ensure better connection not only for the largest agglomerations, but also for the regions, so that their development can be stimulated. However, a more detailed study on potential RS ridership, which should include a transport demand forecasting model and more detailed economic calculations, has to be carried out. SŽDC has called a bid for so called "Rapid Services - Study of Opportunities", that had to be cancelled, because only one eligible applicant remained. Recently, a new bid for the study is being in progress.

\section{Methods}

\subsection{PRINCIPLE OF IPT}

IPT is a special case of periodic timetable, which ensures connections between various $\mathrm{PuT}$ lines in the whole network. For this effect, the following requirements must be fulfilled. All services operate in PuT lines, in unified interval which is equal to $2^{k}$-multiple of basic period (60 min as a rule), where $k$ is an integer. In every PuT line, services from opposite directions meet each other at the same time (symmetry time). This time repeats after half an interval. Should services of two PuT lines enable mutual connections with an equal changing time for each direction, these two $\mathrm{PuT}$ lines must have equal symmetry time. In European long-distance railways, symmetry time slightly before the minute 00 is common. This is called zero symmetry axis. In practice, symmetry times in the minute 57 to 01 are used, which, in the case of hourly interval, implies another symmetry time in the minute 30 . For the $30 \mathrm{~min}$ interval, additional symmetry times in the minutes 15 and 45 occur. An IPT-node is a railway station where connections with services from other PuT lines can be ensured, because the symmetry time is reached there. To achieve connections in every IPT-node, system travel time between them must be ensured. It is an integer multiple of half period. It consists of sum of regular runtimes between two IPTnodes, sum of dwell times and waiting times between them, and of proportional part of dwell, changing or waiting times in mentioned IPT-nodes (it depends which time is limiting in each particular case) 13 . It is obvious that two PuT lines with equal runtimes, which operate on long enough common line section and do not need to be connected for the passenger transfer, can be interposed into a half interval. This interposition is used for more attractive timetable offer. On the other hand, if the transfer is desirable, the trains of two PuT lines run as close as possible after each other (so that they reach the same IPT-node, e.g., in Berne).

\subsection{Operational Concept Economy APPROACH}

The presented methodological approach, although soft and manager-oriented, comprises some firm principles, which will be explained as follows. This approach is intended to be particularized iteratively, with every application. So, in this paper, first version of Operational Concept Economy Approach is introduced. The key idea is that passengers should be offered such travel times and service intervals (headways) and such number of direct services, which are adequate to their potential demand, but as much synergistic effect as possible should be strived to be achieved for every proposed construction (new or modernized one). Such approach goes towards economic efficiency, which is a crucial indicator for political decision necessary for building, let alone EU co-funding of the construction. 
Experience shows that in many Czech feasibility studies, achievement of sufficient economic efficiency was the most complicated part of the study. Travel times should correspond to system travel times according to IPT rules. Of course, system travel time is always considerably larger than a corresponding runtime, because of times for changing between services in the IPT nodes, and necessary time supplement for the sake of timetable stability. Because of high-speed railway dynamics, such supplement should be larger here than by the conventional railway. Runtime calculations are not subject of this paper, but it is obvious, that for approx. $200 \mathrm{~km}$ distant cities Praha and Brno and for system travel time 60 min between them, maximum speed of $200 \mathrm{~km} / \mathrm{h}$ is totally insufficient. So, higher speed, e.g. $350 \mathrm{~km} / \mathrm{h}$, is considered. Moreover, in city centres, only lower speed is possible due to densely built-up areas and probably one more stop in Praha before the centre (Zahradní Město) 6]. If a new HSL is justified by the potential demand, it should be at the same time used by as many trains as possible, to make faster as many connections as possible. Thus, at least central parts of the HS network should serve as "rail highways" for fast enough long-distance, or even fast regional, $\mathrm{PuT}$ lines. This idea leads to requirements for junctions to connect a HSL with conventional rail network. A recent concept of RS of Czech Ministry of Transport [12] corresponds to such idea, because of ensuring fast railway service also for Czech regions. But, because of economy, there should be less junctions with as much $\mathrm{PuT}$ lines using one junction as reasonable. As a rule of thumb, every junction from HS line should be used by minimum 1 pair of trains hourly. The design of PuT lines themselves should also be in compliance with economy. For high-speed railway, a hierarchy in the form of following segments of offer can be defined:

- Fastest PuT lines (HS-A) for the speed up to 350 $\mathrm{km} / \mathrm{h}$, with dedicated EMUs. In Figure 2, such $\mathrm{PuT}$ lines are marked in red colour.

- Long-distance PuT lines (HS-B1) which operate on long sections of fast high-speed lines, so the rolling stock should be able to run 230 to $250 \mathrm{~km} / \mathrm{h}$ to avoid frequent overtaking by trains of higher segment. Rolling stock can vary from EMU to classical trainset, or push-pull units hauled by a locomotive (e.g. Railjet). In Figure 2, such PuT lines are marked in violet colour, and in pink colour, in the case of tilting trains.

- Long-distance PuT lines (HS-B2) which operate on short sections of fast high-speed lines, or they are overtaken by HS-A trains. Thus, for the rolling stock the maximum speed of $200 \mathrm{~km} / \mathrm{h}$ is sufficient. Rolling stock can vary from EMU to classical trainset. In Figure 2 such PuT lines are marked in blue colour.

- Fast regional PuT lines (HS-C), which can achieve significantly lower travel time to the agglomeration centre by using of HSL section. The rolling stock should run at least $160 \mathrm{~km} / \mathrm{h}$ and be interoperable with TSIs required for high-speed railway (for the other segments, this is evident). For maintaining reasonable complexity, this segment is neglected in this paper.

For the sake of economy, the higher segment, the less trainsets should be required. This aim can be achieved by two means: as little number of PuT lines as reasonable, and as little number of trainsets per PuT line as reasonable. But, on the other hand, appropriate service interval, and some reserve trainsets should be ensured. The basic service interval for each $\mathrm{PuT}$ line is considered $60 \mathrm{~min}$. The only exception is international PuT line Warsaw - Vienna, which is of international more than national significance. The basic service interval of $30 \mathrm{~min}$ (of a single PuT line or an interposition of them) is considered for connection of all regional centres above 90000 inhabitants with Praha, Brno or Ostrava, if the system travel time to the particular agglomeration is 1 hour or lower. The HS-A segment should end in cities, which are large enough to justify the most expensive and maintenance sensitive rolling stock. For the HS-A segment between Praha and Brno, a basic interval $15 \mathrm{~min}$ is considered. In some studies, even an interval $10 \mathrm{~min}$ is discussed, but it would complicate operation of HS-B trains on the same HSL. So, the longest possible trains $(400 \mathrm{~m})$, and double-decker trains (such as TGV Duplex) are considered as mostly desirable. The number of four basic HS-A PuT lines (each one with 60 min interval) should not be exceeded. Thus, every HS-A train is economically justified because of service between Praha and Brno. Because of "biggest possible" trains, a 30 min period of HS-A segment between Praha and Ostrava is likely to be sufficient. It is obvious that vast majority of the demand would be national, mostly between large cities. So, for the sake of economy, a standard HS-A trainset consisting of two half-trains (such as ICE 3, but double-decker) is further proposed. This measure would enable eventual disconnection of one trainset in the station, where many passengers leave and only little number of passengers board. Such disconnection enables also direct service to two various destinations. As a rule of thumb for the Czech Republic, middle-sized cities with 30,000 or more inhabitants can be considered as appropriate ends of HS-A PuT lines. It is, however, important that a runtime from regional centre to such city must not exceed approximately 25 minutes. Thus, service for such middle-sized city in 60 min interval would cost only 1 trainset extra (a half-train only). For the HS-B segment, the choice of rolling stock depends on timetable of HSL section used (required maximum speed), and on justification of tilting technology (a long enough conventional line with many curves, and potential time savings related to the population served). The PuT lines should be composed with respect to equal rolling stock requirements on both sides of a metropolis (for 
the Czech Republic, this means in practice Praha and Brno). For the HS-C segment, runtime savings should justify extra costs for "high-speed-compatible" technical equipment of the rolling stock. Thus, such trains should use high-speed line sections both before and after stop in the agglomeration centre. For the feasibility of the proposed operational concept, electrification and upgrading of several mainlines is supposed. Further, a new line from Třebíč to Moravské Budějovice is required, to enable direct connection of Jihlava, Třebíč and Znojmo. For the sake of reasonable scope, timetables are not constructed. It is supposed, that in every IPT-node, slower trains leave after faster trains, if they run on the same line. Thanks to the symmetry of IPT, arrival sequence is symmetric (slower trains arrive before faster ones). The system travel times are estimated on the basis of Kalčík, Janoš et al. 4, and lengthened due to additional stops if needed (by qualified estimation).

\section{Results And Discussion}

The scheme of PuT lines, IPT-nodes and system travel times between large cities is displayed in Figure 2 An interposition into half interval (30 $\mathrm{min})$ is marked by two parallel lines close together.

For the HS-A segment, the interpositions into 30 min and 15 min intervals have resulted in the fact that either Plzeň or Ústí nad Labem, but not both cities, can be connected directly with Ostrava. Considering importance of direct connection of Berlin and Vienna via Praha for the Czech Republic, Ostrava should be connected directly with Plzeň rather than Ústí. Thus, two bundles of HS-A PuT lines emerged:

- Berlin - Dresden - Praha - Brno - Břeclav - Vienna/Bratislava - Budapest and Litvínov/Děčín Ústí nad Labem - Praha - Brno - Zlín

- Munich (or Nuremberg) - Plzeň/Plzeň - Praha - Brno - Ostrava - Petrovice u Karviné - Warsaw/Opava and Plzeň - Praha - Brno - Ostrava Havírov - Žilina

The sign "/" stands for coupling and decoupling of half-trains. For international directions, full trains were only considered for Berlin (because of national demand between Dresden and Berlin) and Žilina, because of traditional "Czechoslovak" passenger demand (e.g. students, workers or tourists). From Plzeň, only a half-train proceeds to Bavaria. In Břeclav, decoupling enables direct service from Praha both to Vienna, and Bratislava (and Budapest). The PuT line, which ends in Ústí nad Labem, can proceed both to Děčín and Teplice, thanks to decoupling. If the line to Litvínov would be upgraded, a half-train can end there. So, service of both branches would cost only 1 half-train extra per branch. From Ostrava, only a half-train would proceed to Warsaw. Thus, the second half-train can proceed to Opava, and even with present runtime it would cost only 1 half-train extra. HS-B1 segment is proposed mostly in Moravia for the connection of
Central Moravia between Brno and Ostrava. The reason for faster trains is the absence of stops directly on the HSL Brno - Ostrava. The absence of clear centre resulted in necessity of more $\mathrm{PuT}$ lines. Olomouc is connected with Brno by a non-stop service every 30 min. Every second train proceeds north-westward to connect Mohelnice, Zábřeh and Šumperk directly with Brno. Due to longer runtime, two extra trains are required. Olomouc is also connected with Ostrava every $30 \mathrm{~min}$. One PuT line proceeds as an express segment to Pardubice and Hradec Králové, the second one as a slower inter-regional train to Pardubice. From Pardubice to Praha, the same PuT line changes to a non-stop segment. Between Praha and Olomouc, an interposition into $30 \mathrm{~min}$ interval is proposed. The interposing PuT line proceeds to Vsetín. Because the last PuT line uses HSL only between Praha and Pardubice, a trainset for $200 \mathrm{~km} / \mathrm{h}$ could be appropriate. Přerov is connected hourly both with Brno and Ostrava. Behind Přerov, both PuT lines proceed as a conventional fast train. Hradec Králové is connected with Praha only hourly. The supplementary connection can be ensured by transfer in Pardubice. The PuT line from Hradec Králové is proposed to be composed of two EMUs, because of further decoupling, so that both Trutnov and Náchod can be connected directly with Praha. Liberec is connected with Praha every 30 min, with only intermediate stop in Mladá Boleslav. Jablonec nad Nisou is connected with Liberec (and hence with Praha) by suburban trains. The same case is Kladno with Praha (but there are supposed fast regional trains, running directly to Praha main station). North-western Bohemia is connected with Praha every $30 \mathrm{~min}$, with likely stop in Louny (for the connection of this peripheral region) between Most and Praha. One of two PuT lines proceeds to Karlovy Vary and Cheb, and, because of the terrain, tilting train operation can save considerable amount of runtime. Both mentioned PuT lines proceed from Praha to Jihlava, but with various stopping. The tilting train as HS-B1 segment runs nonstop, and proceeds to Třebíč and Znojmo (possible proceeding to Vienna is worth consideration), where tilting is supposed to save the runtime. Another PuT line stops in Benešov, and on the HSL in Vlašim and Vysočina (a stop between Pelhřimov and Humpolec, linked to bus and Park+Ride). Overtaking by HS-A trains in some of these stations is very likely - that is why HS-B2 segment is sufficient. From Jihlava, this PuT line proceeds to Havlíčkův Brod and Ždár nad Sázavou. Instead of separate link from HSL to Havlíčkův Brod, a thorough modernization and doubling of the line Jihlava - Havlíčkův Brod is proposed here. Jihlava is connected with Brno every 30 min, with intermediate stop in Velké Meziříčí RS, most likely with overtaking by HS-A segment at the same time. Thus, HS-B2 segment seems to be sufficient. From Jihlava, one PuT line would proceed to Havlíčkův Brod, and the second one to České Budějovice. Modernization of 


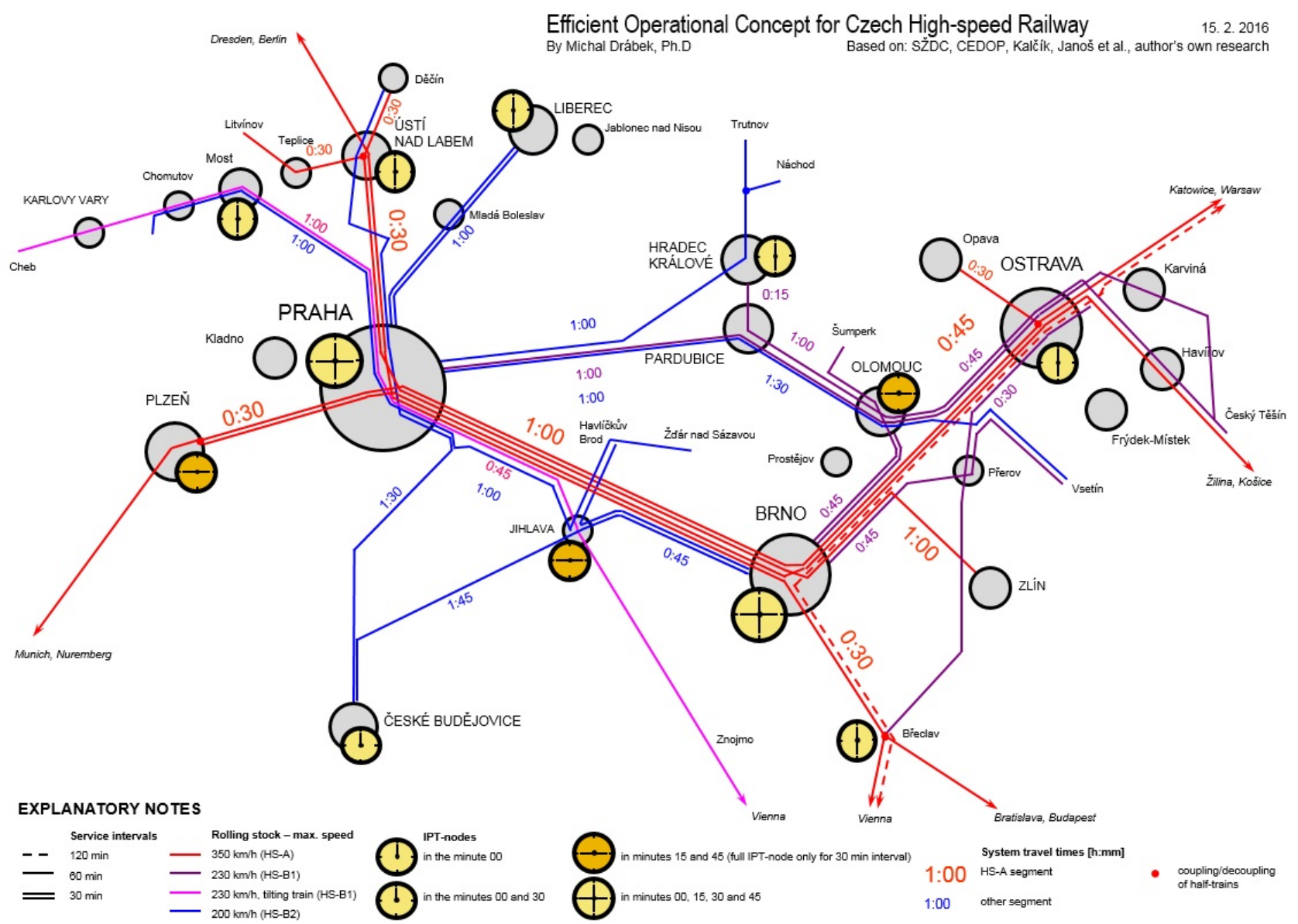

Figure 2. Proposed Operational Concept for HSL network of RS.

the line Jihlava - Veselí nad Lužnicí and a new tunnel Ševětín - Nemanice are supposed to be comlpeted. The last PuT line of HS-B2 segment is Děčín - Ústí nad Labem - Litoměřice - Roudnice nad Labem RS - Praha - Tábor - České Budějovice. The corridor to České Budějovice is supposed to be finished. One of the most important results is a reduction of links from HSLs to conventional lines outside large nodes. For long-distance PuT lines (HS-B1 and HS-B2) there have remained: Litoměřice, Benešov u Prahy (twice), Jihlava (twice), Olomouc (twice) and Přerov (twice) in total 9 links. It is desirable to try to design links near Olomouc and Přerov together as well as to design single-track links, if they would be used by only one pair of trains hourly. Of course, the proposed operational concept implies plenty of alternatives. For instance, a 30 min interval Praha - Hradec Králové, or another PuT line layout for the connection of Jihlava. If the PuT line interval is $60 \mathrm{~min}$, the timetable should be constructed so that additional peak trains (which leads to interposition into $30 \mathrm{~min}$ interval) can be added without any conflict. The probably biggest disadvantage of the RS concept used by the author is that Pardubice cannot be connected with Brno within 1 hour system travel time. The author is aware of alternative concepts of HSL Praha - Brno via Pardubice. But, given that system travel time 1 hour between Praha and Brno is not quite easy to achieve even via Jihlava, the longer HSL via Pardubice would hardly enable such time, even with a non-stop train running up to $350 \mathrm{~km} / \mathrm{h}$.

\section{CONCLUSiON}

The presented operational concept is only a brief layout, which served as a test of Operational Concept Economy Approach, and a feedback for future making this approach more accurate. The author believes than his layout would also contribute to constructive discussion on future Czech RS system, and on the role of HSLs in it. The author considers as an important contribution in this paper, that there were shown close economic interdependencies between operational concept, rolling stock and infrastructure, and the operational concept was designed on the basis of such interdependencies, towards economic efficiency, but not at the expense of runtimes between the largest cities. The Czech RS network always will be an integral part of both European and national transport system. Thus, its layout and construction will be always subject of political decisions. The presented operational concept has clearly demonstrated many possible alternative solutions. Although detailed studies will calculate which alternative brings higher benefits for lower costs, the most likely alternative to be constructed will be, in the 
author's opinion, a result of political compromise or trade-off. But, even by choosing any such sub-optimal alternative the decision makers should keep in mind than it should enable efficient allocation of resources. There is always a high risk not only of construction of excessive infrastructure, but also of inefficient operational concept (too many $\mathrm{PuT}$ lines for too low demand). Thus, every alternative, before its detailed economic assessment, has to be designed cautiously to minimize such risk. The compromises are inevitable, but they should not generate disproportionate extra costs.

\section{ACKNOWLEDGEMENTS}

The author would hereby like to propose a vote of thanks to Mr. Petr Šlegr for his long-standing promotion of highspeed railway in the Czech Republic, which he has crowned by editing and publishing book High Speed Rail Even in the Czech Republic [5]. The author would hereby like to propose a vote of thanks to Dr. Vít Janoš, a supervisor of his doctoral thesis, for initial layout of an operational concept for RS 4], that the author was glad to follow up. The author would hereby like to propose a vote of thanks to Mr. Jiří Kalčík, a freelance road and railway designer, for searching for efficient high-speed lines, both in official studies (e.g. 4]), and in his spare time [5]. So, he has contributed significantly to the concept mentioned above. All engineers enabled the author to follow their ideas from timetabling viewpoint - for instance, in this paper. The author would hereby also like to propose a vote of thanks to SŽDC as a former author's employer, for the occasion to assess five spatial-technical studies of HSLs simultaneously from timetabling viewpoint (in summer 2013). This task has made the author to create his own view on efficient operational concept for the future Czech RS network. His interest in this field has endured up to now, and has resulted in writing this paper. The author hopes it will not remain his last and the most detailed work in this field.

\section{REFERENCES}

[1] European Commission. Directive 2008/57/EC of the European Parliament and of the Council of 17 June 2008 on the interoperability of the rail system within the Community [online], 2011. European Union ,Brussels, http://eur-lex.europa.eu/legal-content/EN/TXT/ PDF/?uri=CELEX : 02008L0057-20110322\&from=EN

[2] European Commission. Regulation (EU) No 1315/2013 of the European Parliament and of the Council of 11 December 2013 on Union guidelines for the development of the trans-European transport network and repealing Decision No 661/2010/EU [online]. 2013. European Union ,Brussels, http://eur-lex.europa.eu/legal-content/EN/ALL/ ?uri=uriserv:0J.L_.2013.348.01.0001.01.ENG

[3] Czech Statistical Office. Populations of Municipalities [online], 2015. [2016-04-30], https://www.czso.cz/ csu/czso/pocet-obyvatel-v-obcich-k-112015.

[4] J. Kalčík, V. Janoš. Operational Traffic Planning Solution for Backbone Network of High-Speed Lines, Study on behalf of Czech Ministry of Transport. Chrást u Plzně: Projektové středisko Kalčík, Czech Republic, 2010. Unpublished.

[5] P. Šlegr et al. High Speed Rail Even in the Czech Republic, 2012. Editors: P. Šlegr, M. Robeš, M. Drábek, M. Stach; ISBN 978-80-905005-0-1.

[6] J. Šulc. Actual Progress of Preparation of Rapid Services in SŽDC. In: Czech Raildays: Building of High-speed Rail System in the Czech Republic. Separate Article [online]. Praha: M-presse plus s.r.o., 2014. In Czech, http://www.railvolution.net/ czechraildays/2014/buletin_szdc.pdf

[7] UIC. High Speed Lines in the World [online], 2014. Paris: UIC, http://old.uic.org/IMG/pdf/20140901_ high_speed_lines_in_the_world.pdf

[8] VOeV UTP: Fact and Arguments in Favour of Swiss Public Transport. p. 46. Bern: VOeV UTP, 2010. In German.

[9] V. Janoš, K. Baudyš. Railway timetable in Czech Republic, In Systemy transportowe Teoria i Praktyka, 2009. ISBN 978-83-926923-1-7.

[10] F. Vichta. Requirements for Public transport System in the Czech Republic, Keynote speech, In Future of Railway Passenger Transport in the Czech Republic, Czech Raildays [online], 2011. Ostrava: Railvolution, [2011-06-14], In Czech, http://www.railvolution.net/ czechraildays/2011/seminare/1.3_md_vichta.pdf

[11] Railhuc Project. Final Results [online], 2014. Brno: KORDIS JMK, ISBN 978-80-260-7787-9, http: //www.railhuc.eu/download/category/126-book2.

[12] J. Kušnír, J. Ilík. Railway in 2030, Keynote speech, In Future of Railway Passenger Transport in the Czech Republic, Czech Raildays [online], 2013. Ostrava: Czech Ministry of Transport, In Czech., http://www.railvolution.net/czechraildays/2013/ seminare/konference-kusnir.pdf.

[13] M. Drábek. Periodic Freight Train Paths in Network, Doctoral thesis, 2014. CTU in Prague, http://takt.fd.cvut.cz/cargo/Drabek_thesis.pdf 